\title{
Museums: Not Just Visiting Spaces but a Driving Force for the Use of Advanced S\&T in the Restoration of Artworks
}

\author{
Blanca de-Miguel-Molina, María de-Miguel-Molina and José Albors-Garrigós \\ Management Department, Universitat Politècnica de València, Camino de Vera Valencia, Spain
}

Correspondence should be addressed to: Blanca de-Miguel-Molina; bdemigu@omp.upv.es

Received date: 8 October 2013; Accepted date: 7 January 2014; Published date: 31 October 2014

Copyright (C) 2014. Blanca de-Miguel-Molina, María de-Miguel-Molina and José Albors-Garrigós. Distributed under Creative Commons CC-BY 3.0

\begin{abstract}
Our paper analyses how museums not only play a traditional role in the cultural service but also act as a driving force for the use of science and technology in the conservation of artworks. Through a bibliometric approach and the use of social network analysis (SNA), we explore co-authorship of scientific articles and we detect how museums look for knowledge bases in science and technology. We also differentiate between institutions and geographical regions in order to find patterns in the cooperation with other institutions. Results indicate that European countries are important nodes in the cooperation for restoration and conservation, and patterns of cooperation indicate that museums look for knowledge bases mainly in restoration institutes and other museums in their own countries. This implies that museums look for analytical and synthetic knowledge out of the museums when they need to apply advanced science and technology in restoration.
\end{abstract}

Keywords: Museums, conservation \& restoration, networks, creative industries.

\section{Introduction}

The conservation and restoration of artworks are included in the industries considered as creative or cultural industries (de-Miguel-Molina et al 2013). The UK Department for Culture, Media and Sports (DCMS) (2009), defined creative industries as "those industries that are based on individual creativity, skill and talent, and which have the potential to create wealth and jobs through developing intellectual property".

The arts, heritage and recreation sectors come under the European classifications NACEs 90, 91, 92 and 93. NACEs 90 and 91 are also part of the Knowledge Intensive
Services (KIS) industries, which are those related to the knowledge-based economy (de-Miguel-Molina et al. 2012; Windrum \& Tomlinson, 1999; Aslesen \& Isaksen, 2007a; Bishop, 2008; Strambach, 2008).

In terms of the arts and cultures sector, Bakhshi and Throsby (2010) discussed the lack of studies on innovation, which has been ignored in studies conducted about creative industries. Although there are good studies about the use of science in the restoration of specific artworks (Casadio et al. 2010, Cotte et al. 2010, Doménech-Carbó et al. 2011, Baglioni et al. 2012, DoménechCarbó et al. 2012), the literature about the importance of open innovation and cooperation between different institutions 
in this subsector of creative industries is scarce. This paper tries to cover this gap.

In short, our paper's goal is to examine cooperation between museums and other institutions in the restoration and conservation of artworks. To reach this objective, we have put forward two questions with reference to cooperation in this activity:

RQ1: Are museums in European countries important participants in cooperation with other institutions?

RQ2: Does a pattern in the cooperation between museums and other institutions exist?

Data were taken from the bibliometric analysis of scientific co-authored papers searched in Elsevier's Scopus database. The final number of articles was 1,656 . These data were cleaned through the VantagePoint software.

Important conclusions are inferred from the results. The first is that the participation of European countries for the application of science and technology in conservation and restoration of artworks is evidenced. The second is that, although many museums write papers by their own, when they co-author papers with other institutions, the latter are mainly located in their own country. These institutions are, mainly, research institutes and other museums. Results also illustrate that museums look for institutions that have different types of knowledge bases: symbolic (arts), analytical (physics and chemistry) and synthetic (engineering).

\section{The Use of S\&T in the Conservation and Restoration of Artworks}

Lazzeretti (2012) has analysed the importance of cooperation between different institutions in the development of laser technology for restoring artworks. She explains how cooperation is mainly between local institutions, which can produce the development of a cluster, like the restoration cluster in Firenze (Italy). However, literature about cooperation in arts activities in an innovation framework, like the scheme explained in the Oslo Manual (2005), is scarce.

The main problem in analysing activities like conservation and restoration is that there are no data in the innovation surveys that some countries elaborate. In the subsector covered in this paper, data for patents would be collected from national surveys if they were available, but it is not the case. One solution is the use of bibliometric approach to cover this gap, and especially scientific articles. Different authors have studied technologies, knowledge and networks (Youtie and Shapira 2008, Leydesdorff and Rafols 2011, Robinson et al. 2013). Abramo et al. (2009) mention that using a bibliometric approach to studying cooperation between institutions, as universities and industries, through co-authorship of scientific articles, also allows the diffusion of knowledge and skills. Moreover, Wall and Boschma (2009) refer to knowledge networks in innovation systems where dissemination occurs both between local and abroad actors. In applying a new technology, Boschma (2005) and Rafols et al. (2010) state that actors require cognitive proximity to absorb new knowledge. These authors also ask if the networks will be local, national or global, and if the proximity will be geographic or cognitive.

Conservation is cited by authors among the main activities in a museum, and essential to preserve its heritage (Papini and Persiani 2004, Kotler et al. 2008). At the end of the XVIII century and throughout the XIX, art collections and catalogues live with research in physics and chemistry applied to artworks restoration. Museum restoration laboratories and departments were set up during the XIX century (Moreira 2008). Therefore, analytical knowledge cooperation co-exists in museums since restoration departments were created. 


\section{Method}

\section{Data}

The data used to measure collaboration are scientific co-authored papers. For bibliometric analysis, we searched keywords "paint*" AND "restoration" OR "conservation" in Elsevier's Scopus database. We obtained publications in international journals about the restoration and conservation of painting artworks. The final number of articles was 1,656. These data were imported to VantagePoint software, which was used to clean up the institutions involved in restoration and conservation, and elaborate matrixes of coauthorship among museums, restoration institutes and universities. Matrixes were elaborated depending on papers: museums with other museums, museums with restoration and conservation institutes, museums with university physics and chemistry departments, and museums with university engineering and Information Technologies departments.

The number of institutions analysed was 222: 94 museums from 26 countries, 41 conservation and restoration institutes, 49 university physics and chemistry departments and 38 university engineering and Information Technologies university departments.

\section{Methodology}

For bibliometric analysis, we used Elsevier's Scopus database and the data were cleaned and prepared using three softwares: VantagePoint, WordStat and QDMiner. Matrixes were elaborated depending on: a) papers that were written by the museums or b) papers that were coauthored between a museum and: other museums (symbolic knowledge), restoration and conservation institutes (symbolic), physics and chemistry departments in universities (analytical), or engineering and Information Technologies departments in universities (synthetic). Moreover, institutions were defined depending on their geographical location: Europe, USA \& Canada, Central \& South America, Asia, Africa, and Oceania. A total of 94 museums were analysed, 26 of which were located in the United States, 53 in Europe, 7 in Asia, 3 in Africa, 2 in Central \& South America and 2 in Oceania.

Networks of 2-mode were represented by means of UCINET6 and NETDRAW software. Centralisation degree for affiliation matrixes was calculated in order to determine which institutions coauthored more papers with museums.

\section{Results}

In this section, we answer the two research questions posed at the start of this paper:

RQ1: Are museums in European countries important participants in cooperation with other institutions?

RQ2: Does a pattern in the cooperation between museums and other institutions exist?

In terms of the first research question, we focus on countries and the importance they have in the science of conservation and restoration of artwork. For this purpose, we elaborate a 1-mode matrix where columns and rows are each country, included in the same order. We have used the number of papers in which every country appears as attributes. Therefore, we represent, in Figure 1, co-authorship between countries, and the size of the nodes represents how important is every country. The figure shows that Italy and the United States are the most important countries. Also, the United Kingdom and Spain are between the most important participants in explaining how to use science and technology in conservation and restoration. 


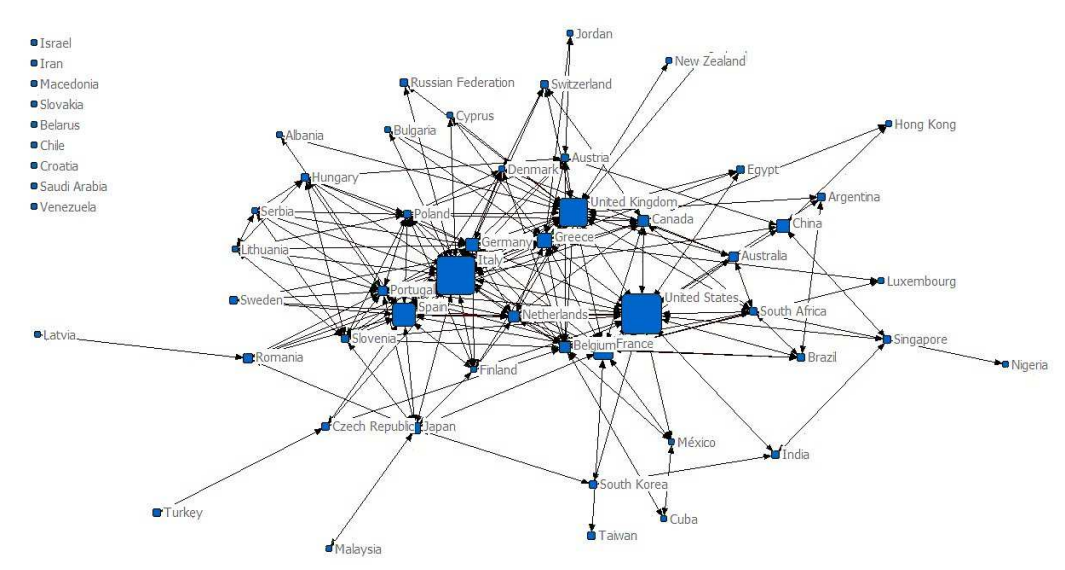

Figure 1: Ranking of countries in co-authorship of papers about conservation and restoration of artworks. Source: compiled by authors based on the Scopus database

In order to analyse in detail the countries that cooperate more in conservation and restoration, we need to eliminate those that do not cooperate. In this case, we eliminate the nodes that appear in the left side in Figure 1: Israel, Iran, Macedonia, Slovakia, Belarus, Chile, Croatia, Saudi Arabia and Venezuela. Once we had eliminated these nodes, we used social network analysis (SNA) to calculate the centrality degree, which calculated how many nodes are connected. Table 1 indicates that Italy is the country with the highest degree of cooperation in papers. The second country in order of appearance is the United Kingdom and the third is the United States. Column "Nrm Degree" indicates that each one of these three countries has more than $10 \%$ of the total connections of the network.

Table 1: Centrality measure: degree

\begin{tabular}{|c|c|c|}
\hline Country & Degree & $\begin{array}{c}\text { Nrm } \\
\text { Degree }\end{array}$ \\
\hline Italy & 105 & 13.67 \\
\hline United Kingdom & 99 & 12.89 \\
\hline United States & 82 & 10.68 \\
\hline France & 59 & 7.68 \\
\hline Greece & 56 & 7.29 \\
\hline Spain & 52 & 6.77 \\
\hline Netherlands & 50 & 6.51 \\
\hline Germany & 47 & 6.12 \\
\hline Belgium & 39 & 5.08 \\
\hline Portugal & 30 & 3.91 \\
\hline Poland & 22 & 2.86 \\
\hline
\end{tabular}




\begin{tabular}{|c|c|c|}
\hline Canada & 19 & 2.47 \\
\hline Japan & 15 & 1.95 \\
\hline Slovenia & 15 & 1.95 \\
\hline Austria & 12 & 1.56 \\
\hline Finland & 11 & 1.43 \\
\hline Romania & 9 & 1.17 \\
\hline South Africa & 9 & 1.17 \\
\hline Hungary & 9 & 1.17 \\
\hline Denmark & 9 & 1.17 \\
\hline Australia & 8 & 1.04 \\
\hline Serbia & 8 & 1.04 \\
\hline Switzerland & 7 & 0.91 \\
\hline Lithuania & 7 & 0.91 \\
\hline China & 6 & 0.78 \\
\hline Brazil & 6 & 0.78 \\
\hline Egypt & 5 & 0.65 \\
\hline Singapore & 5 & 0.65 \\
\hline Sweden & 5 & 0.65 \\
\hline Czech Republic & 4 & 0.52 \\
\hline Argentina & 4 & 0.52 \\
\hline México & 4 & 0.52 \\
\hline Cyprus & 4 & 0.52 \\
\hline India & 3 & 0.39 \\
\hline South Korea & 3 & 0.39 \\
\hline Albania & 3 & 0.39 \\
\hline Bulgaria & 3 & 0.39 \\
\hline Russian Federation & 2 & 0.26 \\
\hline Hong Kong & 2 & 0.26 \\
\hline Ireland & 2 & 0.26 \\
\hline Cuba & 2 & 0.26 \\
\hline Jordan & 2 & 0.26 \\
\hline Luxembourg & 2 & 0.26 \\
\hline Taiwan & 1 & 0.13 \\
\hline Turkey & 1 & 0.13 \\
\hline New Zealand & 1 & 0.13 \\
\hline Malaysia & 1 & 0.13 \\
\hline Nigeria & 1 & 0.13 \\
\hline Latvia & 1 & 0.13 \\
\hline
\end{tabular}

Source: Compiled by authors based on the Scopus database

Blanca de-Miguel-Molina, María de-Miguel-Molina and José Albors-Garrigós (2014), Journal of Administrative Sciences and Technology, DOI: 10.5171/2014.539873 
Next, we calculated the cliques where there are more than three countries. We have found 47 cliques: Italy appeared in 29 cliques, the United Kingdom in 22 and the United States in 17. Moreover, Germany is in 16, Spain in 14, Belgium in 11 and France in 9 cliques. Therefore, participation of European countries in cooperation for application of the science and technology in conservation and restoration of artworks is evidenced.

1: United States Italy United Kingdom Spain France Greece Germany Netherlands Portugal

2: United States Italy United Kingdom Spain Germany Netherlands Finland

3: Italy United Kingdom Spain Germany Portugal Poland

4: Italy United Kingdom Spain Germany Poland Denmark

5: Italy United Kingdom Spain Germany Poland Finland

6: United States Italy United Kingdom France Greece Germany Belgium Netherlands

7: Italy United Kingdom Greece Germany Belgium Austria

8: Italy United Kingdom Germany Belgium Poland Austria

9: Italy United Kingdom Germany Belgium Poland Denmark

10: United States Italy United Kingdom France Netherlands Canada

11: Italy United Kingdom Canada Poland

12: Italy United Kingdom Russian Federation

13: Italy United Kingdom Greece Cyprus

14: Italy United Kingdom Greece Bulgaria

15: United States Italy China
16: Italy China Austria

17: Italy Spain France Japan Portugal

18: Italy Spain Japan Portugal Romania

19: Italy Spain Japan Portugal Slovenia

20: Italy Spain Japan Finland

21: Italy Canada Romania

22: Italy Belgium Czech Republic

23: Italy Spain Czech Republic

24: Italy Germany Portugal Poland Slovenia Hungary Lithuania Serbia

25: Italy Spain Germany Portugal Poland Slovenia

26: United States Italy Spain Germany Portugal Slovenia

27: Italy Germany Belgium Poland Slovenia

28: United States Italy Germany Belgium Slovenia

29: Italy Germany Poland Austria Hungary

30: United States United Kingdom France Canada Australia South Africa

31: United Kingdom Australia Denmark

32: United Kingdom Germany Switzerland Denmark

33: United Kingdom Canada Switzerland

34: United States India South Korea

35: United States India Singapore

36: United States United Kingdom Greece Egypt

37: United States France Belgium Brazil South Africa 
38: United States Brazil Argentina

39: United States United Kingdom Argentina

40: United States United Kingdom France Belgium South Africa

\section{1: United States China Singapore}

42: Spain Greece Netherlands Portugal Sweden

43: United States France Belgium México

44: Belgium México Cuba

45: United Kingdom Spain Albania

46: Greece Austria Jordan

\section{7: France Greece Luxembourg}

An interesting result is shown in Table 2, where we incorporate the co-membership matrix resulted from cliques. We only include, in the table, the most important countries. Results indicate the number of cliques in which every country in the diagonal participate, and the rest of cells represent in how many cliques there are coincidences between countries. For example, the United Kingdom coincides with Italy in 14 cliques; Italy and Germany are jointly in 15 cliques, and Spain and Italy concur in 12 cliques. It is evident that countries cooperated in a high rank with Italy and the United Kingdom.

Table 2: Clique co-membership matrix for the most important participants

\begin{tabular}{|l|c|c|c|c|c|c|c|c|c|}
\hline & $\begin{array}{c}\text { United } \\
\text { States }\end{array}$ & Italy & $\begin{array}{c}\text { United } \\
\text { Kingdom }\end{array}$ & Spain & France & Greece & Germany & China & Belgium \\
\hline United States & 17 & $\mathbf{7}$ & $\mathbf{8}$ & 3 & $\mathbf{7}$ & 3 & 5 & 2 & 5 \\
\hline Italy & 7 & 29 & $\mathbf{1 4}$ & $\mathbf{1 2}$ & 4 & 5 & $\mathbf{1 5}$ & 2 & 7 \\
\hline United Kingdom & 8 & $\mathbf{1 4}$ & 22 & 6 & 5 & 6 & $\mathbf{1 0}$ & 0 & 5 \\
\hline Spain & 3 & $\mathbf{1 2}$ & 6 & 14 & 2 & 2 & 7 & 0 & 0 \\
\hline France & $\mathbf{7}$ & 4 & 5 & 2 & 9 & 3 & 2 & 0 & 4 \\
\hline Greece & 3 & 5 & 6 & 2 & 3 & 9 & 3 & 0 & 2 \\
\hline Germany & 5 & $\mathbf{1 5}$ & $\mathbf{1 0}$ & 7 & 2 & 3 & 16 & 0 & 6 \\
\hline China & 2 & 2 & 0 & 0 & 0 & 0 & 0 & 3 & 0 \\
\hline Belgium & 5 & $\mathbf{7}$ & $\mathbf{5}$ & 0 & 4 & 2 & 6 & 0 & 11 \\
\hline
\end{tabular}

Source: compiled by authors based on the Scopus database

The second objective of this paper is to detect whether there is a pattern in the cooperation between museums and other institutions. Also, the paper looks into which type of knowledge base the museums look for when they are going to undertake the conservation or restoration of any artwork that they are not able to do or they do not have the knowledge needed to do it. For this purpose, we prepare a 2mode network, where the rows are the museums and the columns are the institutions that cooperate with museums. We have differentiated between institutions depending on where they are located, in the same country than the museum or abroad.

Firstly, we represent the entire network in Figure 2. This figure shows that museums write an important part of the papers alone. Moreover, there is no cooperation with institutions located in the left side of the Figure 2 (See Appendix for the meaning of codes). Because the main objective of this paper is to analyse cooperation, we eliminate both institutions that do not cooperate with museums and museums that write papers alone. 


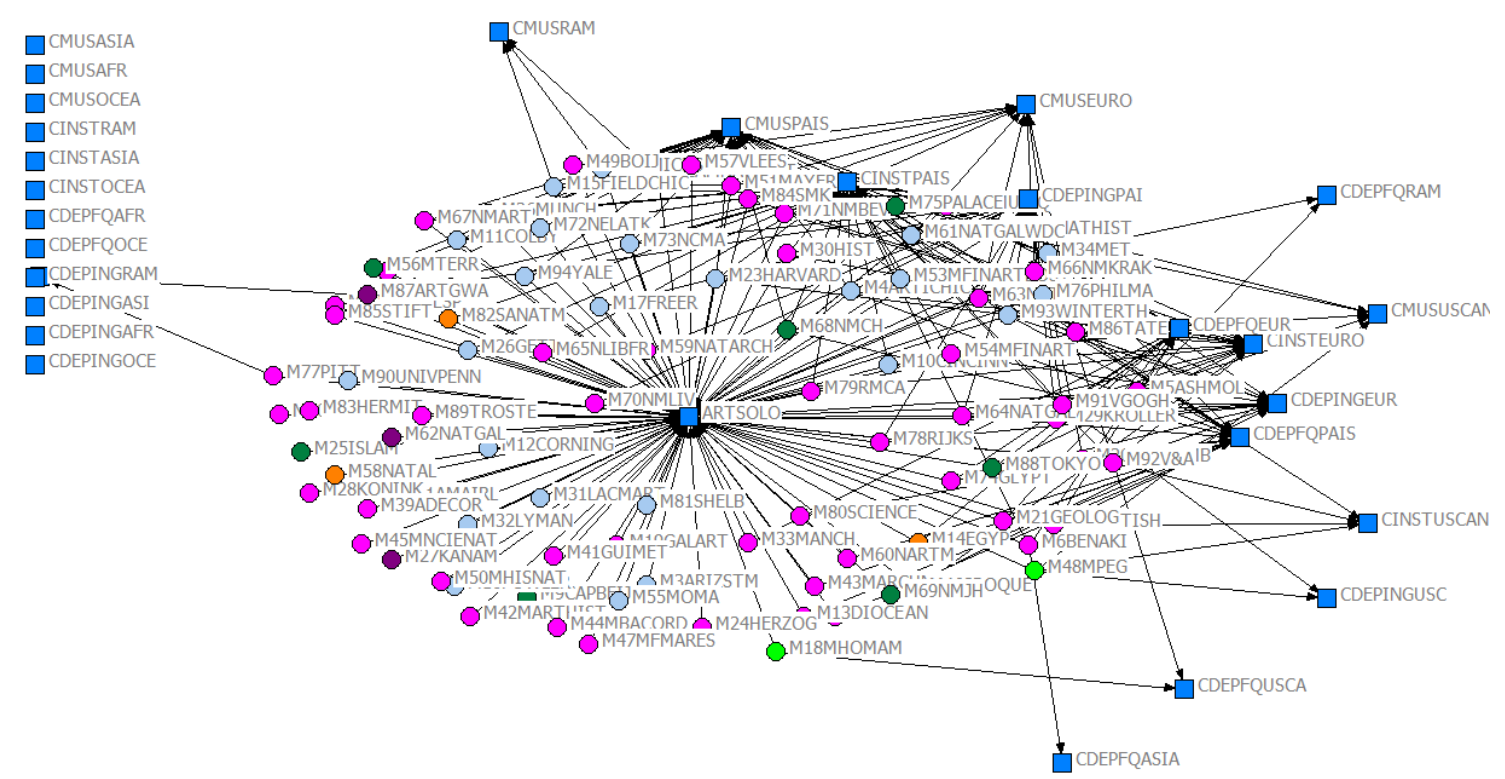

Figure 2: Museums and their cooperation with other institutions

Source: compiled by authors based on the Scopus database

Figure 3 includes the cleaned network. Looking at the figure, we may indicate that museums cooperate mainly with other museums and restoration institutes located in their own country. In order to better determine patterns of cooperation, we calculatedensity, degree, closeness and betweenness. 


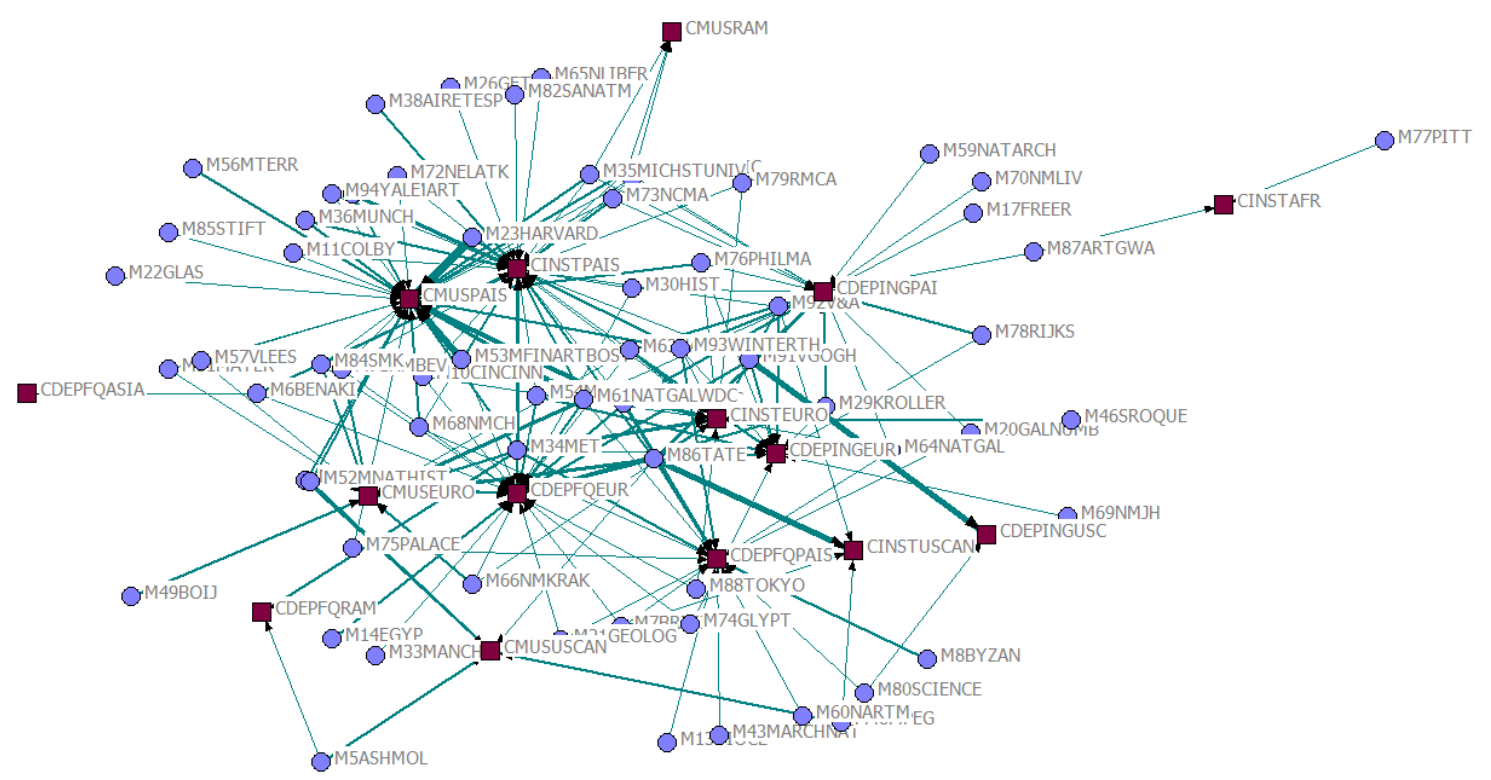

Figure 3: Cooperation between museums and institutions based on co-authorship of papers

Source: compiled by authors based on the Scopus database

Density indicates that in this network the $17.8 \%$ of potential relations is achieved. Moreover, the standard deviation is 2.96, representing high inequality in the distribution of the relations. In the degree column, the higher values are for the important museums, like the Tate (London), the Metropolitan Museum of Art in New York, the Van Gogh Museum (Amsterdam), the National Gallery in Washington DC, the National Gallery in Athens (Greece) and the Winterthur Museum (US). These museums appear in the centre of the network in Figure 3 . Concerning the closeness, museums, with more possibilities to coincide with other museums and cooperate with the same institutions, are the Tate, the National Gallery in Washington DC, and the Metropolitan Museum of Art in New York, the Winterthur Museum (USA) and the Art Institute of Chicago. With respect to betweenness, museums with higher values in the column are those that cooperate both with institutions that are important nodes and with institutions that few museums cooperate with. These museums will be in better position to get information from institutions and other museums. Examples in this group of museums are the Tate (London) and the Metropolitan Museum of Art in New York.

Table 3: Centrality, closeness and betweenness for rows (museums)

\begin{tabular}{|l|r|r|r|r|}
\hline & \multicolumn{1}{|l|}{ Degree } & \multicolumn{1}{l|}{ Closeness } & Betweenness & Eigenvector \\
\hline M2AMNATHIST & 0.27 & 0.71 & 0.02 & 0.16 \\
\hline M4ARTICHIC & 0.33 & $\mathbf{0 . 8 2}$ & 0.04 & 0.22 \\
\hline
\end{tabular}




\begin{tabular}{|c|c|c|c|c|}
\hline M5ASHMOL & 0.13 & 0.48 & 0.00 & 0.01 \\
\hline M6BENAKI & 0.20 & 0.65 & 0.03 & 0.11 \\
\hline M7BRITISH & 0.20 & 0.61 & 0.01 & 0.08 \\
\hline M8BYZAN & 0.07 & 0.51 & 0.00 & 0.03 \\
\hline M10CINCINN & 0.20 & 0.67 & 0.00 & 0.14 \\
\hline M11COLBY & 0.13 & 0.64 & 0.00 & 0.11 \\
\hline M13DIOCE & 0.07 & 0.51 & 0.00 & 0.03 \\
\hline M14EGYP & 0.07 & 0.55 & 0.00 & 0.04 \\
\hline M15FIELDCHIC & 0.27 & 0.71 & 0.02 & 0.16 \\
\hline M17FREER & 0.07 & 0.54 & 0.00 & 0.04 \\
\hline M20GALNUMB & 0.13 & 0.60 & 0.00 & 0.07 \\
\hline M21GEOLOG & 0.13 & 0.60 & 0.00 & 0.07 \\
\hline M22GLAS & 0.07 & 0.56 & 0.00 & 0.05 \\
\hline M23HARVARD & 0.20 & 0.67 & 0.01 & 0.15 \\
\hline M26GETTY & 0.07 & 0.59 & 0.00 & 0.06 \\
\hline M29KROLLER & 0.27 & 0.67 & 0.01 & 0.15 \\
\hline M30HIST & 0.20 & 0.71 & 0.01 & 0.15 \\
\hline M33MANCH & 0.07 & 0.55 & 0.00 & 0.04 \\
\hline M34MET & 0.53 & 0.83 & 0.08 & 0.27 \\
\hline M35MICHSTUNIV & 0.27 & 0.71 & 0.02 & 0.16 \\
\hline M36MUNCH & 0.13 & 0.64 & 0.00 & 0.11 \\
\hline M37MUSIQ & 0.20 & 0.67 & 0.01 & 0.10 \\
\hline M38AIRETESP & 0.07 & 0.59 & 0.00 & 0.06 \\
\hline M43MARCHNAT & 0.07 & 0.51 & 0.00 & 0.03 \\
\hline M46SROQUE & 0.07 & 0.52 & 0.00 & 0.03 \\
\hline M48MPEG & 0.20 & 0.49 & 0.00 & 0.02 \\
\hline M49B0IJ & 0.07 & 0.49 & 0.00 & 0.02 \\
\hline M51MAYER & 0.13 & 0.58 & 0.00 & 0.07 \\
\hline M52MNATHIST & 0.20 & 0.67 & 0.01 & 0.10 \\
\hline M53MFINARTBOST & 0.27 & 0.71 & 0.01 & 0.19 \\
\hline M54MFINART & 0.20 & 0.67 & 0.01 & 0.14 \\
\hline M56MTERR & 0.07 & 0.56 & 0.00 & 0.05 \\
\hline M57VLEES & 0.13 & 0.58 & 0.00 & 0.07 \\
\hline M59NATARCH & 0.07 & 0.54 & 0.00 & 0.04 \\
\hline M60NARTM & 0.07 & 0.51 & 0.00 & 0.03 \\
\hline M61NATGALWDC & 0.40 & 0.84 & 0.05 & 0.24 \\
\hline M63NATGAL & 0.40 & 0.78 & 0.03 & 0.23 \\
\hline M64NATGAL & 0.27 & 0.66 & 0.01 & 0.13 \\
\hline M65NLIBFR & 0.07 & 0.59 & 0.00 & 0.06 \\
\hline
\end{tabular}




\begin{tabular}{|l|r|r|r|r|}
\hline M66NMKRAK & 0.20 & 0.60 & 0.00 & 0.10 \\
\hline M67NMART & 0.13 & 0.64 & 0.00 & 0.11 \\
\hline M68NMCH & 0.20 & 0.70 & 0.01 & 0.14 \\
\hline M69NMJH & 0.07 & 0.51 & 0.00 & 0.03 \\
\hline M70NMLIV & 0.07 & 0.54 & 0.00 & 0.04 \\
\hline M71NMBEV & 0.27 & 0.71 & 0.01 & 0.18 \\
\hline M72NELATK & 0.13 & 0.64 & 0.00 & 0.11 \\
\hline M73NCMA & 0.20 & 0.71 & 0.01 & 0.15 \\
\hline M74GLYPT & 0.13 & 0.58 & 0.00 & 0.07 \\
\hline M75PALACE & 0.13 & 0.61 & 0.00 & 0.07 \\
\hline M76PHILMA & 0.27 & 0.71 & 0.01 & 0.15 \\
\hline M77PITT & 0.07 & 0.35 & 0.00 & 0.00 \\
\hline M78RIJKS & 0.13 & 0.57 & 0.00 & 0.07 \\
\hline M79RMCA & 0.13 & 0.62 & 0.00 & 0.10 \\
\hline M80SCIENCE & 0.07 & 0.51 & 0.00 & 0.03 \\
\hline M82SANATM & 0.07 & 0.59 & 0.00 & 0.06 \\
\hline M84SMK & 0.27 & 0.71 & 0.01 & 0.18 \\
\hline M85STIFT & 0.07 & 0.56 & 0.00 & 0.05 \\
\hline M86TATE & $\mathbf{0 . 6 0}$ & $\mathbf{0 . 8 8}$ & $\mathbf{0 . 1 0}$ & 0.27 \\
\hline M87ARTGWA & 0.13 & 0.55 & 0.05 & 0.04 \\
\hline M88TOKYO & 0.13 & 0.58 & 0.00 & 0.08 \\
\hline M91VGOGH & $\mathbf{0 . 4 0}$ & 0.76 & 0.05 & 0.21 \\
\hline M92V\&A & 0.71 & 0.02 & 0.17 \\
\hline M93WINTERTH & $\mathbf{0 . 8 3}$ & 0.04 & 0.24 \\
\hline M94YALE & 0.64 & 0.00 & 0.11 \\
\hline
\end{tabular}

Source: compiled by authors based on the Scopus database

Institutions that are more demanded by museums to cooperate in restoration and conservation are included in Table 4 . The higher degree, closeness and betweenness are for institutions located in the museum's own country, being the most important restoration institutes and other museums.

Table 4: Centrality, closeness and betweenness for columns (institutions)

\begin{tabular}{|l|r|r|r|r|}
\hline & \multicolumn{1}{|l|}{ Degree } & \multicolumn{1}{l|}{ Closeness } & Betweenness & Eigenvector \\
\hline CMUSPAIS & $\mathbf{0 . 4 1}$ & $\mathbf{0 . 5 2}$ & $\mathbf{0 . 2 2}$ & 0.42 \\
\hline CMUSEURO & 0.15 & 0.44 & 0.05 & 0.19 \\
\hline CMUSUSCAN & 0.08 & 0.42 & 0.03 & 0.06 \\
\hline CMUSRAM & 0.05 & 0.34 & 0.00 & 0.05 \\
\hline CINSTPAIS & $\mathbf{0 . 4 7}$ & $\mathbf{0 . 5 6}$ & $\mathbf{0 . 2 8}$ & 0.55 \\
\hline CINSTEURO & 0.24 & 0.47 & 0.08 & 0.30 \\
\hline
\end{tabular}




\begin{tabular}{|l|l|l|l|r|}
\hline CINSTUSCAN & 0.06 & 0.40 & 0.01 & 0.06 \\
\hline CINSTAFR & 0.03 & 0.28 & 0.03 & 0.00 \\
\hline CDEPFQPAIS & 0.24 & 0.46 & 0.16 & 0.22 \\
\hline CDEPFQEUR & $\mathbf{0 . 3 5}$ & $\mathbf{0 . 5 1}$ & 0.18 & 0.39 \\
\hline CDEPFQRAM & 0.03 & 0.38 & 0.01 & 0.03 \\
\hline CDEPFQASIA & 0.02 & 0.31 & 0.00 & 0.01 \\
\hline CDEPINGPAI & $\mathbf{0 . 3 2}$ & $\mathbf{0 . 5 0}$ & $\mathbf{0 . 2 2}$ & 0.36 \\
\hline CDEPINGEUR & 0.20 & 0.45 & 0.06 & 0.24 \\
\hline CDEPINGUSC & 0.03 & 0.36 & 0.00 & 0.03 \\
\hline
\end{tabular}

Source: compiled by authors based on the Scopus database

A broad analysis of data shows that the institutes that cooperate most with museums are the Getty Conservation Institute (Los Angeles), the Courtauld Institute of Art in London, the Centre for Research and Restoration of the Museums of France, and the Institute of Fine Arts in New York. It is important to indicate that the Getty Institute cooperates especially closely with the Tate Gallery.

In this paper, we point out that museums look for analytical and synthetic knowledge. Analytical knowledge is related to chemistry and physics, and museums cooperate with departments in universities related to this type of knowledge. Some examples about the departments which have cooperated with museums are: the Physics Department of the Politecnico di Milano (Italy), the School of Science in Birkbeck College (London), and the Department of Chemistry in Northwestern University (US). In relation to synthetic knowledge, that is, engineering skills, museums have cooperated with university departments like the Department of Material Science and Engineering in Delft University of Technology (Netherlands) or the Bioengineering and Radiology Department in the University of Washington (Seattle, United States).

Papers about the use of science and technology in the restoration and conservation of artworks tend to focus on the different applications of the spectroscopy, like gas chromatographymass spectrometry. Other important groups of papers cover the use of the electron microscopy and the X-ray diffraction. The use of such advanced techniques explains why museums need to cooperate with other institutions.

\section{Conclusion}

This paper focuses on analysing the cooperation between museums and other institutions in the use of science and technology when they are going to restore any artwork. The literature about cooperation in creative activities is scarce, especially in relation to the use of advanced science and technology. Lazzaretti's (2012) analysis of the restoration cluster in Firenze, Italy, is circumscribed to laser technology.

Our paper analyses the activity of restoration and cooperation in artworks in a global approach, so we are able to differentiate if networks are national or global, and which countries are more important in cooperation.

Data were obtained through a bibliometric analysis of papers' co-authorship, which gives a wide quantity of data about cooperation in restoration. Then, we have applied network analysis to represent cooperation.

Results indicate that European countries are important participants in the cooperation with both other European and abroad countries. Moreover, there is a pattern in the cooperation between museums and other institutions. Museums tend to cooperate with research institutes and with other museums located in their own countries. Finally, there are important collaborations with university departments of physics, chemistry and engineering. This 
implies that museums look for analytical and synthetic knowledge out of the museum when they need to apply advanced science and technology in restoration.

\section{Acknowledgments}

The authors would like to thank the Spanish Ministry of Economy and Competitiveness and Universitat Politècnica de València (Spain) for funding this research (HAR2012-32060 Project, Research Projects no. 2677-UPV and PAID2012-487-UPV)

\section{References}

1. Abramo, G., D'Angelo, CA., DiCosta, F. and Solazzi, M. (2009), 'Universityindustry collaboration in Italy: A bibliometric examination', Technovation, 29 (6/7), 498-507.

2. Aslesen, HW. and Isaksen, A. (2007), 'Knowledge intensive business services and urban industrial development', The Service Industries Journal, 27(3), 321-338.

3. Baglioni, M., Giorgi, R., Berti, D., and Baglioni, P. (2012), 'Smart cleaning of cultural heritage: a new challenge for soft nanoscience', Nanoscale, 4, 42-53.

4. Bakhshi, H. and Throsby, D. (2010), 'Culture of Innovation An economic analysis of innovation in arts and cultural organisations'. NESTA. London, UK, http://www.nesta.org.uk/sites/default/fil es/culture_of_innovation.pdf

5. Bishop, P. (2008), 'Spatial spillovers and the growth of knowledge intensive services', Tijdschrift voor Economische en Sociale Geografie, 99(3), 281-292.

6. Boschma, RA. (2005), 'Proximity and Innovation: A Critical Assessment', Regional Studies, 39(1), 61-74.

7. Casadio, F., Leona, M., Lombardi, JR., and van Duyne, R. (2010), 'Identification of organic colorants in fibers, paints, and glazes by surface enhanced Raman
Spectroscopy', Accounts of Chemical Research, 43(6), 782-791.

8. Cotte, M., Susini, J., Dik, J., and Janssens, K. (2010), 'Synchrotron-based Xray absorption Spectroscopy for art conservation: looking back and looking forward', Accounts of Chemical Research, 43(6), 705-714.

9. DCMS (2009), Creative industries economic estimates statistical bulletin. https://www.gov.uk/government/publica tions/creative-industries-economicestimates-january-2009

10. De-Miguel-Molina, B., Hervás-Oliver, JL., Boix, R., and de-Miguel-Molina, M .(2012), 'The importance of creative industry agglomeration in explaining the wealth of European regions', European Planning Studies, 20(8), 1243-1262.

11. De-Miguel-Molina, B., Hervás-Oliver, JL., de-Miguel-Molina, M. and Hedderich, B. (2013), 'Do Museums innovate in the Conservation and Restoration of Artworks? Differences between countries', Dirección y Organización, 50, 17-30.

12. Doménech-Carbó, MT., Silva, MF., Aura-Castro, E., Fuster-López, L., Kröner, S., Martínez-Bazán, ML., Más-Barberá, X., Mecklenburg, MF., Osete-Cortina, L., Doménech, A., Gimeno-Adelantado, JV., and Yusá-Marco, DJ. (2011), 'Study of behaviour on simulated daylight ageing of artists' acrylic and poly (vinyl acetate) paint films', Analytical and Bioanalytical Chemistry, 399(9), 2921- 2937.

13. Doménech-Carbó, A., DoménechCarbó, MT., Peiró-Ronda, MA., MartínezLázaro, I., and Barrio-Martín, J. (2012), 'Application of the voltammetry of microparticles for dating archaeological lead using polarization curves and electrochemical impedance spectroscopy', Journal of Solid State Electrochemistry, 16(7), 2349-2356.

14. Kotler, NG., Kotler, P. and Kotler, WI. (2008), Museum Marketing \& Strategy, $2^{\text {a }}$ Ed, Jossey-Bass, Wiley, USA. 
15. Lazzeretti, L. (2012), Cluster creative per I beni culturali, Firenze University Press.

16. Leydesdorff, L. and Rafols, I. (2011), 'Local Emergence and Global Diffusion of Research Technologies: An Exploration of Patterns of Network Formation', Journal of the American Society for Information Science and Technology, 62(5), 846-860.

17. Moreira Teixeira, JC. (2008), La teoría en la práctica de la conservación / restauración del arte contemporáneo, 9aㅗ Jornada de Conservación de Arte Contemporáneo, Museo Nacional Centro de Arte Reina Sofía, Madrid, p. 209-218.

18. OECD (2005), 'Oslo Manual, $3^{\text {rd }}$ ed. The measurement of scientific and technological activities. Proposed guidelines for collecting and interpreting technological innovation data'. www.oecd.org/dataoecd/35/61/2367580 .pdf

19. Papini, F. and Persiani, N. (2004), 'The enhancement of art assets through the establishment of foundations: the case of the Marino Marini foundation in Florence'. Art Cities, Cultural Districts and Museums. Lazzeretti, L. (ed), Firenze University Press, Italy, p. 139-161.

20. Rafols, I., Porter, A. and Leydesdorff, L. (2010), 'Science Overlay Maps: A NewTool for Research Policy and Library Management', Journal of the American Society for Information Science and Technology, 61(9), 1871-1887.
21. Robinson, DKR., Huang, L., Guo, Y., and Porter, AL. (2013), 'Forecasting Innovation Pathways (FIP) for new and emerging science and technologies', Technological Forecasting \& Social Change, 80(2), 267-285.

22. Strambach, S. (2008), 'Knowledgeintensive business services (KIBS) as drivers of multilevel knowledge dynamics', International Journal of Services Technology and Management, $10(2 / 3 / 4), 152-174$.

23. Wall, A. and Boschma, RA. (2009), 'Applying social network analysis in economic geography: framing some key analytic issues', The Annals of Regional Science, 43(3), 739-756.

24. Windrum, $P$. and Tomlinson, $M$. (1999), 'Knowl- edge-intensive services and international com- petitiveness: A tour country comparison', Technology Analysis and Strategic Management, 11(3), 391-408.

25. Youtie, J. and Shapira, P. (2008), 'Mapping the nanotechnology enterprise: a multi-indicator analysis of emerging nanodistricts in the US South', Journal of Technology Transfer, 33(2), 209-223.

\section{Appendix}

\begin{tabular}{|l|l|}
\hline \multicolumn{1}{|c|}{ Code } & \multicolumn{1}{c|}{ Institution } \\
\hline CMUSPAIS & Cooperate with museums in their own country \\
\hline CMUSEURO & Cooperate with museums in Europe \\
\hline CMUSUSCAN & Cooperate with museums in USA and Canada \\
\hline CMUSRAM & Cooperate with museums in rest of America \\
\hline CMUSASIA & Cooperate with museums in Asia \\
\hline
\end{tabular}

Blanca de-Miguel-Molina, María de-Miguel-Molina and José Albors-Garrigós (2014), Journal of Administrative Sciences and Technology, DOI: 10.5171/2014.539873 


\begin{tabular}{|c|c|}
\hline CMUSAFR & Cooperate with museums in Africa \\
\hline CMUSOCEA & Cooperate with museums in Oceania \\
\hline CINSTPAIS & Cooperate with research institutes in their own country \\
\hline CINSTEURO & Cooperate with research institutes in Europe \\
\hline CINSTUSCAN & Cooperate with research institutes in USA and Canada \\
\hline CINSTRAM & Cooperate with research institutes in rest of America \\
\hline CINSTASIA & Cooperate with research institutes in Asia \\
\hline CINSTAFR & Cooperate with research institutes in Africa \\
\hline CINSTOCEA & Cooperate with research institutes in Oceania \\
\hline CDEPFQPAIS & Cooperate with departments of physics and chemistry in their own country \\
\hline CDEPFQEURO & Cooperate with departments of physics and chemistry in Europe \\
\hline CDEPFQUSCAN & Cooperate with departments of physics and chemistry in USA and Canada \\
\hline CDEPFQRAM & Cooperate with departments of physics and chemistry in rest of America \\
\hline CDEPFQASIA & Cooperate with departments of physics and chemistry in Asia \\
\hline CDEPFQAFR & Cooperate with departments of physics and chemistry in Africa \\
\hline CDEPFQOCEA & Cooperate with departments of physics and chemistry in Oceania \\
\hline CDEPINGPAIS & Cooperate with departments of engineering and IT in their own country \\
\hline CDEPINGEURO & Cooperate with departments of engineering and IT in Europe \\
\hline CDEPINGUSCAN & Cooperate with departments of engineering and IT in USA and Canada \\
\hline CDEPINGRAM & Cooperate with departments of engineering and IT in rest of America \\
\hline CDEPINGASIA & Cooperate with departments of engineering and IT in Asia \\
\hline CDEPINGAFR & Cooperate with departments of engineering and IT in Africa \\
\hline CDEPINGOCEA & Cooperate with departments of engineering and IT in Oceania \\
\hline
\end{tabular}

\begin{tabular}{|c|c|c|c|}
\hline COUNTRY & REGION & NMUSEUM & Museum \\
\hline UNITED STATES & NORTH AMERICA & M1AMAIRL & $\begin{array}{c}\text { American Airlines C.R. Smith } \\
\text { Museum, Forth Worth, TX, } \\
\text { United States }\end{array}$ \\
\hline UNITED STATES & NORTH AMERICA & M2AMNATHIST & $\begin{array}{c}\text { American Museum of Natural } \\
\text { History, Interdepartmental } \\
\text { Laboratories, Central Park } \\
\text { West at 79th Street, New York, } \\
\text { NY 10024, United States }\end{array}$ \\
\hline UNITED STATES & NORTH AMERICA & M3ARIZSTM & $\begin{array}{c}\text { Arizona State Museum, } \\
\text { University of Arizona, United } \\
\text { States }\end{array}$ \\
\hline UNITED STATES & NORTH AMERICA & M4ARTICHIC & Art Institute of Chicago, United \\
\hline
\end{tabular}




\begin{tabular}{|c|c|c|c|}
\hline & & & States \\
\hline UNITED KINGDOM & EUROPE & M5ASHMOL & $\begin{array}{l}\text { Ashmolean Museum, College of } \\
\text { Arts, Oxford, United Kingdom }\end{array}$ \\
\hline GERMANY & EUROPE & M6BENAKI & $\begin{array}{c}\text { Benaki Museum, Conservation } \\
\text { Department, Koumpari 1, } \\
10674 \text { Athens, Greece } \\
\end{array}$ \\
\hline UNITED KINGDOM & EUROPE & M7BRITISH & $\begin{array}{c}\text { British Museum, Great Russell } \\
\text { Street, London, WC1B 3DG, } \\
\text { United Kingdom }\end{array}$ \\
\hline GREECE & EUROPE & M8BYZAN & $\begin{array}{c}\text { Byzantine Museum of } \\
\text { Thessaloniki, Leoforou Stratou } \\
\text { St 2,546 } 40 \text { Thessaloniki, } \\
\text { Macedonia, Greece } \\
\end{array}$ \\
\hline CHINA & ASIA & M9CAPBEIJ & $\begin{array}{c}\text { Capital museum Beijing, } \\
\text { Division of Preservation and } \\
\text { Conservation, Beijing } 100045, \\
\text { China } \\
\end{array}$ \\
\hline UNITED STATES & NORTH AMERICA & M10CINCINN & $\begin{array}{c}\text { Cincinnati Art Museum, } 953 \\
\text { Eden Park Drive, Cincinnati, } \\
\text { OH 45202, United States }\end{array}$ \\
\hline UNITED STATES & NORTH AMERICA & M11COLBY & Colby College Museum of Art \\
\hline UNITED STATES & NORTH AMERICA & M12CORNING & $\begin{array}{c}\text { Corning Museum of Glass, } \\
\text { United States }\end{array}$ \\
\hline SPAIN & EUROPE & M13DIOCE & $\begin{array}{c}\text { Diocesan Museum of Sacred } \\
\text { Art, Bilbao, Spain }\end{array}$ \\
\hline EGYPT & AFRICA & M14EGYP & $\begin{array}{c}\text { Egyptian Museum, Department } \\
\text { of Restoration, Ministry of } \\
\text { Antiquities, Cairo, Egypt }\end{array}$ \\
\hline UNITED STATES & NORTH AMERICA & M15FIELDCHIC & $\begin{array}{c}\text { Field Museum, Chicago, United } \\
\text { States } \\
\end{array}$ \\
\hline UNITED STATES & NORTH AMERICA & M16FOWLER & $\begin{array}{c}\text { Fowler Museum, University of } \\
\text { California, Cotsen Institute of } \\
\text { Archaeology, Los Angeles, CA } \\
\text { 90095-1510, United States }\end{array}$ \\
\hline UNITED STATES & NORTH AMERICA & M17FREER & $\begin{array}{c}\text { Freer Gallery of Art, Arthur M. } \\
\text { Sackler Gallery, Smithsonian } \\
\text { Institution, Washington, DC } \\
20560-0707 \\
\end{array}$ \\
\hline BRAZIL & CSAMERICA & M18МHOMАМ & $\begin{array}{c}\text { Fund. Museu do Homem } \\
\text { Americano, Saõ Raimundo } \\
\text { Nonato, Piaui, Brazil } \\
\end{array}$ \\
\hline ROMANIA & EUROPE & M19GALART & $\begin{array}{c}\text { Galeriile de Artǎ Transilvania, } \\
\text { Brașov, Romania }\end{array}$ \\
\hline ITALY & EUROPE & M20GALNUMB & $\begin{array}{c}\text { Galleria Nazionale dell'Umbria, } \\
\text { Corso Vannucci, } 06123 \\
\text { Perugia, Italy }\end{array}$ \\
\hline SWITZERLAND & EUROPE & M21GEOLOG & $\begin{array}{l}\text { Geological Museum of the } \\
\text { Canton Vaud, Bâtiment } \\
\text { Anthropole, 1015 Lausanne, } \\
\text { Switzerland }\end{array}$ \\
\hline GERMANY & EUROPE & M22GLAS & $\begin{array}{c}\text { Glasmuseum Hentrich, Stiftung } \\
\text { museum kunst Palast, }\end{array}$ \\
\hline
\end{tabular}




\begin{tabular}{|c|c|c|c|}
\hline & & & Düsseldorf, Germany \\
\hline UNITED STATES & NORTH AMERICA & M23HARVARD & $\begin{array}{c}\text { Harvard University Art } \\
\text { Museums, } 32 \text { Quincy Street, } \\
\text { Cambridge, MA 02138, United } \\
\text { States }\end{array}$ \\
\hline GERMANY & EUROPE & M24HERZOG & $\begin{array}{c}\text { Herzog Anton Ulrich-Museum, } \\
\text { Museumstraße I, D38100 } \\
\text { Braunschweig, Germany }\end{array}$ \\
\hline MALAYSIA & ASIA & M25ISLAM & $\begin{array}{c}\text { Islamic Arts Museum, } \\
\text { Curatorial Affairs Department, } \\
\text { Kuala Lumpur, Malaysia }\end{array}$ \\
\hline UNITED STATES & NORTH AMERICA & M26GETTY & $\begin{array}{l}\text { J. Paul Getty Museum, Los } \\
\text { Angeles, CA, United States }\end{array}$ \\
\hline AUSTRALIA & OCEANIA & M27KANAM & $\begin{array}{c}\text { Kanamkek-Yile Ngala Museum, } \\
\text { Wadeye, NT 0822, Australia }\end{array}$ \\
\hline BELGIUM & EUROPE & M28KONINK & $\begin{array}{c}\text { Koninklijk Museum voor } \\
\text { Schone Kunsten, Antwerp, } \\
\text { Belgium }\end{array}$ \\
\hline NETHERLANDS & EUROPE & M29KROLLER & $\begin{array}{c}\text { Kröller-Müller Museum, } \\
\text { Conservation Department, } \\
\text { Houtkampweg 6, NL-6731AW } \\
\text { Otterlo, Netherlands }\end{array}$ \\
\hline AUSTRIA & EUROPE & M30HIST & $\begin{array}{c}\text { Kunsthistorisches Museum, } \\
\text { Conservation Science } \\
\text { Department, Burgring 5, A- } \\
1010 \text { Vienna, Austria } \\
\end{array}$ \\
\hline UNITED STATES & NORTH AMERICA & M31LACMART & $\begin{array}{l}\text { Los Angeles County Museum of } \\
\text { Art, Los Angeles, United States }\end{array}$ \\
\hline UNITED STATES & NORTH AMERICA & M32LYMAN & $\begin{array}{c}\text { Lyman Allyn Art Museum, } 625 \\
\text { Williams St., New London, CT } \\
\text { 06320, United States }\end{array}$ \\
\hline UNITED KINGDOM & EUROPE & M33MANCH & $\begin{array}{c}\text { Manchester Museum, } \\
\text { University of Manchester, } \\
\text { Manchester M13 9PL, United } \\
\text { Kingdom } \\
\end{array}$ \\
\hline UNITED STATES & NORTH AMERICA & M34MET & $\begin{array}{l}\text { Metropolitan Museum of Art, } \\
\text { New York, United States }\end{array}$ \\
\hline UNITED STATES & NORTH AMERICA & M35MICHSTUNIV & $\begin{array}{c}\text { Michigan State University } \\
\text { Museum, East Lansing, MI } \\
\text { 48824, United States }\end{array}$ \\
\hline NORWAY & EUROPE & M36MUNCH & $\begin{array}{c}\text { Munch Museum, Teyengata 53, } \\
\text { 0578, Oslo, Norway }\end{array}$ \\
\hline FRANCE & EUROPE & M37MUSIQ & $\begin{array}{c}\text { Musée de la Musique, } \\
\text { Laboratoire de Recherche et de } \\
\text { Restauration, Cite la Musique, } \\
221 \text { avenue Jean Jaures, } 75019 \\
\text { Paris, France }\end{array}$ \\
\hline FRANCE & EUROPE & M38AIRETESP & $\begin{array}{c}\text { Musée de l'Air et de l'Espace, } \\
\text { Aéroport du Bourget, BP 173, } \\
93352 \text { Le Bourget Cedex, } \\
\text { France }\end{array}$ \\
\hline FRANCE & EUROPE & M39ADECOR & $\begin{array}{c}\text { Musée des Arts décoratifs, } \\
\text { Ucad, } 107 \text { Rue de Rivoli, } 75001\end{array}$ \\
\hline
\end{tabular}




\begin{tabular}{|c|c|c|c|}
\hline & & & Paris, France \\
\hline FRANCE & EUROPE & M40LOUVRE & $\begin{array}{c}\text { Musée du Louvre, } \\
\text { Département des Objets d'Art, } \\
\text { F-75058 Paris Cedex 01, } \\
\text { France }\end{array}$ \\
\hline FRANCE & EUROPE & M41GUIMET & Musée Guimet \\
\hline SWITZERLAND & EUROPE & M42MARTHIST & $\begin{array}{c}\text { Musées d'Art et d'Hist., } \\
\text { Laboratoire de Recherche, CP } \\
\text { 3432, CH-1211 Genève 3, } \\
\text { Switzerland } \\
\end{array}$ \\
\hline ITALY & EUROPE & M43MARCHNAT & $\begin{array}{c}\text { Museo Archeologico Nazionale, } \\
\text { P.zza Duomo 13, } 33043 \\
\text { Cividale del Friuli Udine, Italy }\end{array}$ \\
\hline SPAIN & EUROPE & M44MBACORD & $\begin{array}{l}\text { Museo de Bellas Artes de } \\
\text { Córdoba, Spain }\end{array}$ \\
\hline SPAIN & EUROPE & M45MNCIENAT & $\begin{array}{c}\text { Museo Nacional de Ciencias } \\
\text { Naturales (CSIC), C/ Jose } \\
\text { Gutierrez Abascal 2, E-28006 } \\
\text { Madrid, Spain } \\
\end{array}$ \\
\hline PORTUGAL & EUROPE & M46SROQUE & $\begin{array}{c}\text { Museu de S. Roque, Santa Casa } \\
\text { Misericordia Lisboa, Largo } \\
\text { Trindade Coelho, 1200-470 } \\
\text { Lisboa, Portugal } \\
\end{array}$ \\
\hline SPAIN & EUROPE & M47MFMARES & $\begin{array}{c}\text { Museu Frederic Marès, } \\
\text { Conservation Department, } \\
\text { Institut de Cultura de } \\
\text { Barcelona, Pça Sant Iu 5-6, } \\
\text { 08002 Barcelona, Spain } \\
\end{array}$ \\
\hline BRAZIL & CSAMERICA & M48MPEG & $\begin{array}{c}\text { Museu Paraense Emilio Goeldi } \\
\text { (MPEG), Universidade de São } \\
\text { Paulo, C P 399, CEP 66000, } \\
\text { Belém, PA, Brazil } \\
\end{array}$ \\
\hline NETHERLANDS & EUROPE & M49BOIJ & $\begin{array}{c}\text { Museum Boijmans Van } \\
\text { Beuningen, Museumpark 18- } \\
\text { 20, } 3015 \text { CX Rotterdam, } \\
\text { Netherlands } \\
\end{array}$ \\
\hline FRANCE & EUROPE & M50MHISNAT & $\begin{array}{c}\text { Muséum d'Histoire Naturelle, } \\
28 \text { Boulevard des Belges, } \\
69000 \text { Lyon, France } \\
\end{array}$ \\
\hline BELGIUM & EUROPE & M51MAYER & $\begin{array}{c}\text { Museum Mayer van den Bergh, } \\
\text { Lange Gasthuisstraat 19, } 2000 \\
\text { Antwerpen, Belgium }\end{array}$ \\
\hline FRANCE & EUROPE & M52MNATHIST & $\begin{array}{c}\text { Museum National d'Histoire } \\
\text { Naturelle de Paris, UMR 5198, } \\
\text { CNRS-MNHN, Departement de } \\
\text { Prehistoire du Institut de } \\
\text { Paleontologie Humaine, } 1 \text { rue } \\
\text { Rene Panhard, } 75013 \text { Paris, } \\
\text { France }\end{array}$ \\
\hline UNITED STATES & NORTH AMERICA & M53MFINARTBOST & $\begin{array}{l}\text { Museum of Fine Arts, Boston, } \\
\text { MA 02115, United States }\end{array}$ \\
\hline HUNGARY & EUROPE & M54MFINART & $\begin{array}{c}\text { Museum of Fine Arts, Dózsa Gy. } \\
\text { út } 41, \mathrm{H}-1146 \text { Budapest, }\end{array}$ \\
\hline
\end{tabular}




\begin{tabular}{|c|c|c|c|}
\hline & & & Hungary \\
\hline UNITED STATES & NORTH AMERICA & M55MOMA & $\begin{array}{c}\text { Museum of Modern Art, } \\
\text { Conservation Department, } 11 \\
\text { West 53d St., New York, NY } \\
10019\end{array}$ \\
\hline CHINA & ASIA & M56MTERR & $\begin{array}{c}\text { Museum of the Terracotta } \\
\text { Warriors and Horses of Qin } \\
\text { Shihuang, Lintong, 710600, } \\
\text { China }\end{array}$ \\
\hline BELGIUM & EUROPE & M57VLEES & $\begin{array}{c}\text { Museum Vleeshuis, } \\
\text { Vleeshouwersstraat 38-40, } \\
\text { 2000 Antwerpen, Belgium }\end{array}$ \\
\hline SOUTH AFRICA & AFRICA & M58NATAL & $\begin{array}{c}\text { Natal Museum, Private Bag } \\
\text { 9070, Pietermaritzburg 3200, } \\
\text { South Africa } \\
\end{array}$ \\
\hline GREECE & EUROPE & M59NATARCH & $\begin{array}{l}\text { National Archaeological } \\
\text { Museum of Greece }\end{array}$ \\
\hline BELARUS & EUROPE & M60NARTM & $\begin{array}{l}\text { National Art Museum of the } \\
\text { Republic of Belarus, } 20 \text { Lenin } \\
\text { St., Minsk 220030, Belarus }\end{array}$ \\
\hline UNITED STATES & NORTH AMERICA & M61NATGALWDC & $\begin{array}{c}\text { National Gallery of Art, } \\
\text { Scientific Research } \\
\text { Department, Fourth and } \\
\text { Constitution Avenue NW, } \\
\text { Washington, DC 20565, United } \\
\text { States } \\
\end{array}$ \\
\hline AUSTRALIA & OCEANIA & M62NATGAL & $\begin{array}{c}\text { National Gallery of Australia, } \\
\text { Conservation Department, GPO } \\
\text { Box 1150, Canberra, ACT 2601, } \\
\text { Australia }\end{array}$ \\
\hline GREECE & EUROPE & M63NATGAL & $\begin{array}{c}\text { National Gallery, Alexandros } \\
\text { Soatzos Museum, Athens, } \\
\text { Greece }\end{array}$ \\
\hline UNITED KINGDOM & EUROPE & M64NATGAL & $\begin{array}{c}\text { National Gallery, Scientific } \\
\text { Department, Trafalgar Square, } \\
\text { London WC2N 5DN, United } \\
\text { Kingdom }\end{array}$ \\
\hline FRANCE & EUROPE & M65NLIBFR & $\begin{array}{c}\text { National Library of France, } \\
\text { Paris, France }\end{array}$ \\
\hline POLAND & EUROPE & M66NMKRAK & $\begin{array}{c}\text { National Museum in Kraków, } \\
\text { ul. Krupnicza 26, 31-123 } \\
\text { Kraków, Poland } \\
\end{array}$ \\
\hline NORWAY & EUROPE & M67NMART & $\begin{array}{c}\text { National Museum of Art, } \\
\text { Architecture and Design, P.b } \\
7014 \text { (St Olavs Plass), NO- } \\
\text { 0130, Oslo, Norway }\end{array}$ \\
\hline CHINA & ASIA & M68NMCH & $\begin{array}{c}\text { National Museum of China, } \\
\text { Center for Conservation, } \\
\text { Beijing, 100006, China } \\
\end{array}$ \\
\hline JAPAN & ASIA & M69NMJH & $\begin{array}{l}\text { National Museum of Japanese } \\
\text { History, Museum Science } \\
\text { Division, Research } \\
\text { Department, 117, Jonai-cho, }\end{array}$ \\
\hline
\end{tabular}

Blanca de-Miguel-Molina, María de-Miguel-Molina and José Albors-Garrigós (2014), Journal of Administrative Sciences and Technology, DOI: 10.5171/2014.539873 


\begin{tabular}{|c|c|c|c|}
\hline & & & $\begin{array}{l}\text { Sakura-shi, Chiba 285-8502, } \\
\text { Japan }\end{array}$ \\
\hline UNITED KINGDOM & EUROPE & M70NMLIV & $\begin{array}{c}\text { National Museums Liverpool, } \\
\text { Conservation Technologies, } \\
\text { National Conservation Centre, } \\
\text { Whitechapel, Liverpool, United } \\
\text { Kingdom }\end{array}$ \\
\hline DENMARK & EUROPE & M71NMBEV & $\begin{array}{c}\text { Nationalmuseets } \\
\text { bevaringsafdeling, IC } \\
\text { Modewegsvej, Brede, DK-2800 } \\
\text { Kgs. Lyngby, Denmark } \\
\end{array}$ \\
\hline UNITED STATES & NORTH AMERICA & M72NELATK & $\begin{array}{l}\text { Nelson-Atkins Museum of Art, } \\
\text { Kansas City }\end{array}$ \\
\hline UNITED STATES & NORTH AMERICA & M73NCMA & $\begin{array}{l}\text { North Carolina Museum of Art, } \\
2110 \text { Blue Ridge Road, Raleigh, } \\
\text { NC } 27607 \text {, United States }\end{array}$ \\
\hline DENMARK & EUROPE & M74GLYPT & $\begin{array}{c}\text { Ny Carlsberg Glyptotek, Dantes } \\
\text { Plads 7, Copenhagen 1556, } \\
\text { Denmark } \\
\end{array}$ \\
\hline CHINA & ASIA & M75PALACE & $\begin{array}{l}\text { Palace Museum, Technology } \\
\text { and Science Department, } \\
\text { Beijing, 100009, China }\end{array}$ \\
\hline UNITED STATES & NORTH AMERICA & M76PHILMA & $\begin{array}{c}\text { Philadelphia Museum of Art, } \\
\text { Box 7646, Philadelphia, PA } \\
19101 \\
\end{array}$ \\
\hline UNITED KINGDOM & EUROPE & M77PITT & $\begin{array}{l}\text { Pitt Rivers Museum, University } \\
\text { of Oxford, United Kingdom }\end{array}$ \\
\hline NETHERLANDS & EUROPE & M78RIJKS & $\begin{array}{c}\text { Rijksmuseum, Department of } \\
\text { Conservation and Restoration, } \\
\text { Netherlands } \\
\end{array}$ \\
\hline BELGIUM & EUROPE & M79RMCA & $\begin{array}{c}\text { Royal Museum for Central } \\
\text { Africa, Laboratory of Wood } \\
\text { Biology and Xylarium, Belgium }\end{array}$ \\
\hline UNITED KINGDOM & EUROPE & M80SCIENCE & $\begin{array}{l}\text { Science Museum London, } \\
\text { Chemistry, United Kingdom }\end{array}$ \\
\hline UNITED STATES & NORTH AMERICA & M81SHELB & $\begin{array}{c}\text { Shelburne Museum } \\
\text { Conservation, PO Box 10, } 5555 \\
\text { Shelburne Road, Shelburne, VT } \\
\text { 05482, United States }\end{array}$ \\
\hline SOUTH AFRICA & AFRICA & M82SANATM & $\begin{array}{c}\text { South Africa's National } \\
\text { Museum, Rock Art Department }\end{array}$ \\
\hline RUSSIA & EUROPE & M83HERMIT & $\begin{array}{l}\text { State Hermitage Museum, } \\
\text { Scientific Department }\end{array}$ \\
\hline DENMARK & EUROPE & M84SMK & $\begin{array}{c}\text { Statens Museum for Kunst } \\
\text { (SMK), Sølvgade 48-50, DK- } \\
1307 \text { Copenhagen K, Denmark }\end{array}$ \\
\hline GERMANY & EUROPE & M85STIFT & $\begin{array}{c}\text { Stiftung museum kunst palast, } \\
\text { Ehrenhof 4-5, } 40479 \\
\text { Düsseldorf, Germany } \\
\end{array}$ \\
\hline UNITED KINGDOM & EUROPE & M86TATE & $\begin{array}{l}\text { Tate Britain, Millbank, London } \\
\text { SWIP, 4RG, United Kingdom }\end{array}$ \\
\hline AUSTRALIA & OCEANIA & M87ARTGWA & $\begin{array}{l}\text { The Art Gallery of Western } \\
\text { Australia, Perth Cultural }\end{array}$ \\
\hline
\end{tabular}




\begin{tabular}{|c|c|c|c|}
\hline & & & $\begin{array}{c}\text { Centre, Perth WA 6000, } \\
\text { Australia }\end{array}$ \\
\hline JAPAN & ASIA & М88TOKYO & $\begin{array}{c}\text { Tokyo National Museum, Dept. } \\
\text { of Cultural Properties, } \\
\text { Conservation Division, 19-9 } \\
\text { Ueno-Koen, Taito-ku, Tokyo } \\
\text { 110-8712, Japan }\end{array}$ \\
\hline UNITED KINGDOM & EUROPE & M89TROSTE & $\begin{array}{c}\text { Trostre Wk. Cottage/Indust. } \\
\text { Museum, Corus Packaging } \\
\text { Plus, Trostre Works, Llanelli, } \\
\text { Carmarthenshire } \\
\end{array}$ \\
\hline UNITED STATES & NORTH AMERICA & M90UNIVPENN & $\begin{array}{l}\text { University Museum, University } \\
\text { of Pennsylvania, United States }\end{array}$ \\
\hline NETHERLANDS & EUROPE & M91VGOGH & $\begin{array}{l}\text { Van Gogh Museum, Paulus } \\
\text { Potterstraat 7,1070 AJ } \\
\text { Amsterdam, Netherlands }\end{array}$ \\
\hline UNITED KINGDOM & EUROPE & M92V\&A & $\begin{array}{c}\text { Victoria and Albert Museum, } \\
\text { Conservation Department, } \\
\text { Science Section, South } \\
\text { Kensington, London SW7 2RL, } \\
\text { United Kingdom } \\
\end{array}$ \\
\hline UNITED STATES & NORTH AMERICA & M93WINTERTH & $\begin{array}{c}\text { Winterthur Museum, } \\
\text { Winterthur, DE, United States }\end{array}$ \\
\hline UNITED STATES & NORTH AMERICA & M94YALE & Yale University Art Gallery \\
\hline
\end{tabular}

